\title{
Development and evaluation of the Lake Multi-biotic Integrity Index for Dongting Lake, China
}

\author{
Xing WANG, ${ }^{1,2}$ Binghui ZHENG, ${ }^{1,2 *}$ Lusan LIU, ${ }^{1,2}$ Lijing WANG ${ }^{1,2}$ \\ ${ }^{1}$ State Key Laboratory of Environmental Criteria and Risk Assessment, Chinese Research Academy of Environmental Sciences, Beijing \\ 100012; ${ }^{2}$ State Environmental Protection Key Laboratory of Drinking Water Source Protection, Chinese Research Academy of Envi- \\ ronmental Sciences, Beijing 100012, China \\ *Corresponding author: zhengbh@craes.org.cn
}

\begin{abstract}
A Lake Multi-biotic Integrity Index (LMII) for the China's second largest interior lake (Dongting Lake) was developed to assess the water quality status using algal and macroinvertebrate metrics. Algae and benthic macroinvertebrate assemblages were sampled at 10 sections across 3 subregions of Dongting Lake. We used a stepwise process to evaluate properties of candidate metrics and selected ten for the LMII: Pampean diatom index, diatom quotient, trophic diatom index, relative abundance diatoms, Margalef index of algae, percentage of sensitive diatoms, percentage of facultative individuals, percentage of Chironomidae individuals, percentage of predators individuals, and total number of macroinvertebrate taxa. We then tested the accuracy and feasibility of the LMII by comparing the correlation with physical-chemical parameters. Evaluation of the LMII showed that it discriminated well between reference and impaired sections and was strongly related to the major chemical and physical stressors $(r=0.766, P<0.001)$. The re-scored results from the 10 sections showed that the water quality of western Dongting Lake was good, while that of southern Dongting Lake was relatively good and whereas that of eastern Dongting Lake was poor. The discriminatory biocriteria of the LMII are suitable for the assessment of the water quality of Dongting Lake. Additionally, more metrics belonging to habitat, hydrology, physics and chemistry should be considered into the LMII, so as to establish comprehensive assessment system which can reflect the community structure of aquatic organisms, physical and chemical characteristics of water environment, human activities, and so on.
\end{abstract}

Key words: Algae, macroinvertebrate, metrics, bioassessment, water quality, Dongting Lake.

Received: February 2015. Accepted: May 2015.

\section{INTRODUCTION}

Aquatic biological assemblages are useful indicators for environmental monitoring of water quality because they integrate the effects of natural variation and anthropogenic stressors (Lane and Brown, 2007; Ma et al., 2008). Algae are also amongst the most widely used indicators of biological integrity and physicochemical conditions in aquatic ecosystems (Hill et al., 2003; Miller et al., 2006; Zalack et al., 2010; Wu et al., 2012). Macroinvertebrate assemblages or metrics have also been extensively used for bioassessment of fresh water systems by environmental agencies and researchers (Plafkin et al., 1989; Resh et al., 1995; Blocksom et al., 2002; Chessman et al., 2007; Blocksom et al., 2009; Menetrey et al., 2011; Ogren and Huckins, 2014). Since 1990s, the water quality bioassessment by using single biotic index began to be displaced by the integrated water quality bioassessment based on multiple biotic indices (Kerans and Karr, 1994; Weigel et al., 2002; Blocksom et al., 2002). However, there are several problems in the actual operation and assessment as followed: i) the growth of aquatic organisms is influenced by not only water quality but also parameters of physics, chemistry, climate, hydrology and so on, increasing the random errors of sampling; ii) the preci- sion of identification of specimens may effect the accuracy of bioassessment; iii) the biometrics of a single assemblage can only represent one side of the communities and functions, or respond to limited stressors, which may also effect the accuracy of water status assessment.

Therefore, the use of at least two assemblages has been suggested for more robust biological assessment of condition, as each assemblage may respond differently to potential stressors (Yoder and Rankin, 1995). Multi-biotic indicators and metrics for fish, algae, zooplankton, or macroinvertebrate assemblage condition have been developed for streams (Angermeier et al., 2000; McCormick et al., 2001; Klemm et al., 2003; Whittier et al., 2007; Chon et al., 2013) and lakes (O’Connor et al., 2000; Wilcox et al., 2002; Kane et al., 2009). However, there are still some inadequacies in the present multi-assemblages assessment, for example, the subjectivity of the choice of bio-indices, and the lack of rigorous screening based on discrimination and redundancy of the chosen indices, leading to some alternative indices been left off during the establishing of the Multi-biotic Integrity Index. So far, the multi-assemblages assessment has not yet been used in the lakes of China, that is why we need to establish 
a Multi-biotic Integrity Index based on multi-assemblages to assess the water status of the lakes in China, so as to respond more aspects of potential stressors.

Dongting Lake, the second largest interior lake in the north-eastern part of Hunan Province in China, is located at $28^{\circ} 30^{\prime}-30^{\circ} 20^{\prime} \mathrm{N}$ and $111^{\circ} 40^{\prime}-113^{\circ} 40^{\prime} \mathrm{E}$ in the middle Yangtze River region (Du et al., 2001; Li et al., 2007). This lake drains into the Yangtze and is fed by the four middle Yangtze tributaries (collectively known as the Four Tributaries) flowing into the lake from the northwest. To the south and southwest of the Dongting Lake exist four rivers, which are Xiangjiang, Zishui, Yuanjiang and Lishui (Li et $a l ., 2007)$. These do not belong to the Yangtze drainage basin and also flow into the lake with a large amount of sediment and freshwater discharge. Over the past 150 years, the lake area has decreased from about 6000 to $2000 \mathrm{~km}^{2}$ due to both natural siltation and human activity, such as littoral land reclamation. The present-day lake has a U-shape and consists of 3 regions, which are western Dongting Lake, southern Dongting Lake and eastern Dongting Lake. The whole lake occupies a water area of $1307 \mathrm{~km}^{2}$ and water depth of $6.39 \mathrm{~m}$ on the average, and can expand to $2681 \mathrm{~km}^{2}$ and $23.5 \mathrm{~m}$ during the annual flood season and shrink to $710 \mathrm{~km}^{2}$ in the annual dry season. The heavily populated Dongting Lake basin is one of China's leading rice-producing regions; it is also known for its production of cotton and fish. (Li et al., 2007; Wang et al., 2013). For the past decades, the Dongting Lake has experienced intensifying human activity just like agriculture, industrial manufacture, deforestation and so on, and majority pollutants of point and non-point sources were inflowed to Dongting Lake, for example, farmland fertilizer, living and industrial sewage, fossil fuels, leading to the decreases of algal and macroinvertebrate biodiversity (Dai et al., 2000; Zhang et al., 2002; Li, 2005; Wang et al., 2012) and increases of tolerant macroinvertebrate and nutritional levels (Li, 2005; Xie et al., 2007; Zhong and Chen, 2011).

In this study, we developed and tested the Lake Multibiotic Integrity Index (LMII) using a training data set and a testing data set of algae and benthic macroinvertebrate, respectively, from Dongting Lake. Our specific objectives were to: i) develop a LMII based on algal and macroinvertebrate metrics, so as to assess the effects of human disturbances on the water quality status of Dongting Lake; ii) deduce the water quality status of the study area by implementing the developed LMII; iii) test the accuracy and feasibility of the LMII by comparing the correlation with physical-chemical parameters.

\section{METHODS}

\section{Study area}

The study area consists of three regions in the whole Dongting Lake: western Dongting Lake, southern Dongt- ing Lake and eastern Dongting Lake. The name of sampling sections in the whole Dongting Lake were Potou (S1); Nanzui (S2); Jiangjiazui (S3); Wanzi Lake (S4); Hengling Lake (S5); Yugongmiao (S6); Lujiao(S7); EastDongting Lake (S8); Dongting Lake outlet (S9); Bigsmall west Lake (S10). Fig. 1 shows the general location of the study area. In details, the average water depth is $6 \mathrm{~m}$ and the bottom is mainly composed by yellow and black sand in Potou and Nanzui, whereas $8 \mathrm{~m}$ depth of water and yellow silt of bottom in Jiangjiazui and Wanzi Lake, the four sampling sections belong to western Dongting Lake which is dominated by Phragmites australis, Miscanthus sacchariflorus, Carex tristachya, Potamogeton distinctus and Cyperus rotundus L.; the average water depth is $5 \mathrm{~m}$ and the bottom is mainly composed by yellow sand in Yugongmiao and Lujiao, whereas $8 \mathrm{~m}$ depth of water and yellow silt of bottom in Hengling Lake, the three sampling sections belong to southern Dongting Lake which is dominated by Phragmites australis, Carex tristachya, Utricularia, Myriophyllum verticillatum, Nelumbonucifera, and Polygonum flaccidum Meism; the average water depth is $10 \mathrm{~m}$ and the bottom is mainly composed by yellow silt in East-Dongting Lake, Dongting Lake outlet and Big-small West Lake, the three sampling sections belong to eastern Dongting Lake, which is dominated by Phragmites australis, Carex tristachya, Hydrillaverticillata, Euryale ferox, Lemna minor and Typhaangustifolia.

\section{Sampling and processing of algae and benthic macroinvertebrates}

The sampling of algae in both left and right side of each section was carried out from bottom to top in the water column with a 25-mesh sieve in March, June, September and October of 2012. Collected organisms were stored in $1.5 \%(\mathrm{~V} / \mathrm{V})$ Lugol's. The sampling of benthic macroinvertebrates in both left and right side of each section was carried out with a Peterson grab $\left(1 / 16 \mathrm{~m}^{2}\right)$ during the same sampling event as algae. The obtained sediment samples were elutriated with a 60-mesh sieve, and then transferred to a white tray for further sorting of benthic macroinvertebrates. Sorted organisms were stored in $75 \%$ ethanol. The samples were brought back to the laboratory where these organisms were identified to the lowest taxonomic level possible using stereoscopes and counted. Re-counting and re-identification was conducted on $10 \%$ of algae and macroinvertebrate samples as a quality assurance measure. The number of algae cells in each species or genus was calculated by determining the cells averaged across the two samples collected at each side of the sections and converted to cells per liter, while benthic macroinvertebrate individuals in each species or genus was calculated by determining the individuals averaged across the two samples collected at each side of the sections and converted to individuals per square meter. 


\section{Water quality measures and characterization of reference and impairment sections}

Water quality samples were collected and composited at the same time and locations as algae and macroinvertebrates sampling. For each sample location, in situ measurements of conductivity (EC), $\mathrm{pH}$, dissolved oxygen (DO), and temperature $(\mathrm{T})$ were averaged from three depths $(0.5$ $\mathrm{m}$ from the surface, bottom and mid-column). The measurements of total phosphorus (TP), total nitrogen (TN), ammonia nitrogen $\left(\mathrm{NH}_{3}-\mathrm{N}\right)$, potassium permanganate $\left(\mathrm{COD}_{\mathrm{Mn}}\right)$, chemical oxygen demand $\left(\mathrm{COD}_{\mathrm{Cr}}\right)$, biochemical oxygen demand $\left(\mathrm{BOD}_{5}\right)$, chlorophyll a (Chla) and faecal coliform count (FC) were carried out with reference to Chinese EPA methods for the monitoring and analysis of water and wastewater (China EPA, 2002).

A Chinese surface water quality standard was applied to help define bioregional reference and impairment criteria for each section (Tab. 1).

\section{Metric selection and calibration}

Seventeen algae metrics and thirty-nine macroinvertebrate metrics were selected for evaluation for the multi-biotic index (Tabs. 2 and 3). Statistical analyses for screening candidate metrics were performed with SPSS version 13.0

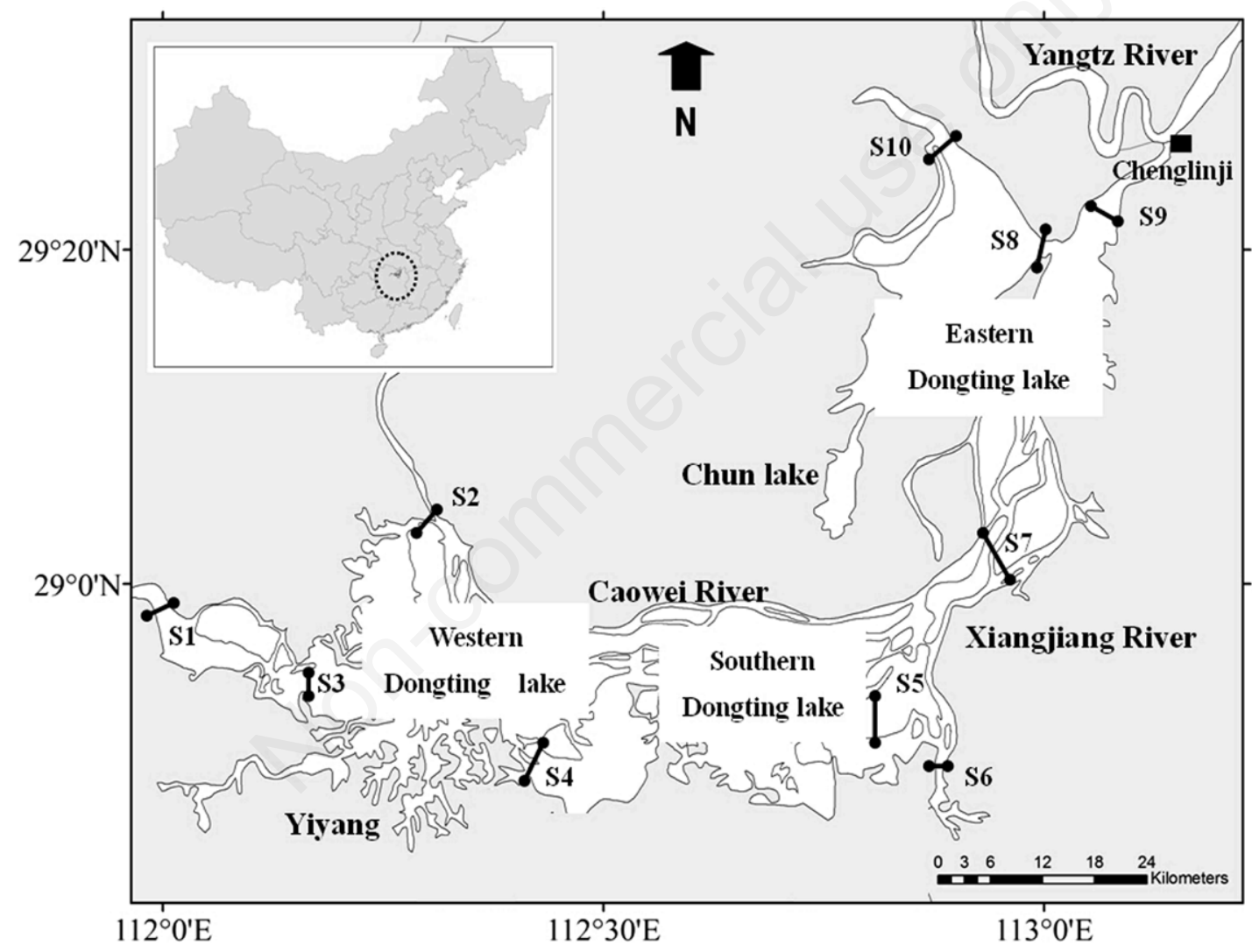

Fig. 1. Sampling sections of Dongting Lake in 2012. S1, Potou; S2, Nanzui; S3, Jiangjiazui; S4, Wanzi Lake; S5, Hengling Lake; S6, Yugongmiao; S7, Lujiao; S8, East-Dongting Lake; S9, Dongting Lake outlet; S10, Big-small West Lake.

Tab. 1. Discriminatory factors for reference and impaired water.

\begin{tabular}{|c|c|c|c|c|c|c|}
\hline & $\begin{array}{c}\rho(\mathrm{EC}) \\
\mathrm{ms} / \mathrm{m}\end{array}$ & $\rho(\mathrm{DO})$ & $\rho\left(\mathrm{COD}_{\mathrm{Mn}}\right)$ & $\begin{array}{c}\rho\left(\mathrm{COD}_{\mathrm{Cr}}\right) \\
\mathrm{mg} / \mathrm{L}\end{array}$ & $\rho\left(\mathrm{BOD}_{5}\right)$ & $\rho\left(\mathrm{NH}_{3}-\mathrm{N}\right)$ \\
\hline Reference & $\leq 26$ & $\geq 8.0$ & $\leq 2.0$ & $\leq 15.0$ & $\leq 3.0$ & $\leq 0.20$ \\
\hline Impaired & $>26$ & $<8.0$ & $>2.0$ & $>15.0$ & $>3.0$ & $>0.20$ \\
\hline
\end{tabular}

$E C$, electrical conductivity; $D O$, dissolved oxygen; $C O D_{M n}$, potassium permanganate; $C O D_{C}$ chemical oxygen demand; $B O D_{5}$, biochemical oxygen demand. 
(SPSS Inc., Chicago, IL, USA). The metrics were calculated by determining the average of four sampling results.

A stepwise process based on EPA technical guidance (1998) for establishing biocriteria for lakes and reservoirs was used to evaluate the metrics for use in a multimetric index. Three characteristics were evaluated for each metric: i) discriminatory power; ii) redundancy; and iii) relationship with stressors.

\section{Discriminatory power}

We defined discriminatory power of a metric as the ability of that metric to distinguish between reference and impaired sections and evaluated metrics by examining their distributions by using box-and-whisker plots. The degree of overlap between interquartile (IQ) ranges (the box) of reference and impaired sections was considered a signal of the discriminatory capability of the metric. Using the system developed by Barbour et al. (1996), metrics scoring 2 or 3 were retained for further analysis.

\section{Redundancy}

We evaluated redundancy among metrics to ensure that each metric in the final index provides new information. Using the remaining metrics, Pearson correlation coefficients was used to identify highly correlated metrics. A simple correlation alone is not considered sufficient to regard two metrics as redundant (EPA, 1998). It is suggested that usually a tight correlation $(r>0.75)$ and a linear relationship is necessary to consider two metrics redundant. Pairs of metrics with lower correlation coefficients usually showed enough scatter or nonlinearity to indicate that each metric provided some new information. We selected one metric from each group of redundant metrics. We retained the one that had a tight correlation $(r<0.75)$ for further analysis (Maxted et al., 2000).

\section{Relationship with stressors}

The remaining metrics were evaluated to find those related to potential stressors. The potential stressors included limnological variables, such as $\mathrm{DO}, \mathrm{pH}, \mathrm{TP}, \mathrm{TN}$, $\mathrm{NH}_{3}-\mathrm{N}, \mathrm{COD}_{\mathrm{Mn}}, \mathrm{COD}_{\mathrm{Cr}}, \mathrm{BOD}_{5}$, Chla and fecal coliform count. Principal component analysis (PCA) with SPSS version 13.0 was used to chosen the major potential stressors and canonical correspondence analysis (CCA) was used to identify important stressor-metric relationships. Only metrics showing a high relationship with at least one potential stressor were retained.

\section{Scoring of metrics}

We used the $95^{\text {th }}$ or $5^{\text {th }}$ percentile value because this method avoids using anomalously high or low outliers as the best expected value (EPA, 1999). The frequency was distributed at the clean sites of metrics $90^{\text {th }}$ percentile and the maximum value. Calculated metric values were converted (normalized) to metric scores of 5, 3 or 1 depending on their proximity to the optimal values. For the metrics whose values decreased with the increase of stress (positive metrics), metric values above the $50^{\text {th }}$ percentile were scored as 5 , metric values between and including the $10^{\text {th }}$ and $50^{\text {th }}$ percentiles were scored as 3 , and all metric values below the $10^{\text {th }}$ percentile were scored as 1 . For the metrics whose values increased with the increase of stress

Tab. 2. Candidate bioticmetrics of algae (Huang et al., 1982; Shen et al., 1990; Kelly and Whitton, 1995; Gomez and Licuris, 2001; Barbour et al., 1999; Muscio, 2002; Griffith et al., 2005; Bellinger et al., 2006; Yin et al., 2012).

\begin{tabular}{|c|c|c|}
\hline Category & Metrics and serial number & Responses \\
\hline Richness and abundance & $\begin{array}{l}\mathrm{P}_{1}: \text { Relative abundance diatoms (RAD) } \\
\mathrm{P}_{2}: \text { Algal cell abundance } \\
\mathrm{P}_{3}: \text { Margalef species richness diversity index } \\
\mathrm{P}_{4}: \text { Relative abundance } \text { Cymbella } \mathrm{sp} \text {. }\end{array}$ & $\begin{array}{l}\text { Decrease } \\
\text { Decrease } \\
\text { Decrease } \\
\text { Decrease }\end{array}$ \\
\hline Taxonomic composition & $\begin{array}{l}\mathrm{P}_{5}: \text { Shannon-Wiener species diversity index } \\
\mathrm{P}_{6}: \text { Simpson species diversity index } \\
\mathrm{P}_{7}: \text { Pielou evenness index } \\
\mathrm{P}_{8}: \text { Species number } \\
\mathrm{P}_{9}: \text { Percent motile diatoms (PMD) } \\
\mathrm{P}_{10}: \text { Generic diatom index (IDG) } \\
\mathrm{P}_{11}: \text { Diatom quotient } \\
\mathrm{P}_{12}: \% \text { Cymbella } \mathrm{sp} . \\
\mathrm{P}_{13}: \% \text { Navicula } \mathrm{sp} .\end{array}$ & $\begin{array}{l}\text { Decrease } \\
\text { Decrease } \\
\text { Decrease } \\
\text { Decrease } \\
\text { Increase } \\
\text { Decrease } \\
\text { Increase } \\
\text { Decrease } \\
\text { Increase }\end{array}$ \\
\hline Tolerance and intolerance index & $\begin{array}{l}\mathrm{P}_{14}: \text { Pollution tolerance index for diatoms (PTI) } \\
\mathrm{P}_{15}: \text { Percent sensitive Diatoms (PSD) } \\
\mathrm{P}_{16}: \text { Trophic diatom index (TDI)73 } \\
\mathrm{P}_{17}: \text { Pampean diatom index (PDI\&IDP)74 }\end{array}$ & $\begin{array}{l}\text { Decrease } \\
\text { Decrease } \\
\text { Increase } \\
\text { Decrease }\end{array}$ \\
\hline
\end{tabular}

$P_{\mathrm{i}}$ : algae index. 
(negative metrics), metric values below the $50^{\text {th }}$ percentile were scored as 5 , metric values between and including the $50^{\text {th }}$ and $90^{\text {th }}$ percentiles were scored as 3 , and metric values above the $90^{\text {th }}$ percentile were scored as 1 .

A final multimetric index of biotic integrity was created by summing selected metrics of algae and macroinvertebrate to establish the Lake Multi-biotic Integrity Index (LMII).

\section{Power and accuracy analysis}

To assess the ability of the LMII to distinguish sections or conditions, we ran power and accuracy analysis based on estimates of temporal and spatial variability. We compared with the LMII of its component metric scores and potential stressors of its comprehensive pollution index scores (PI) (Lin, 1985), and considered that the LMII was suitable for the assessment of the water quality of Dongting Lake when the similarity rate of the results was more than $60 \%$. Alternatively, in the same way, we chose the data of seven sampling sections (Potou, Jiangjiazui, Nanzui, Wanzi Lake, Yugongmiao, Lujiao and East Dongting Lake) investigated in January, May and September in 2011 to verify the power and accuracy of the LMII. Finally, we used Spearman rank correlation to determine the relationship between LMII and PI scores based on the 2011 and 2012 sampling results of 17 sections. The calculated formula as below:

$\mathrm{LMII}=\sum\left(\sum_{1} \mathrm{P}_{i}+\sum_{2} \mathrm{M}_{j}\right)$

$\mathrm{PI}=\sum_{1} \omega_{i 1} \cdot p_{i}+\sum_{2} \omega_{i 2} \cdot p_{i}$

Tab. 3. Candidate bioticmetrics of macroinvertebrates (Blocksom et al., 2002; Klemm et al., 2003).

\begin{tabular}{|c|c|c|}
\hline Category & Metrics and serial number & Response \\
\hline Richness and density & $\begin{array}{l}M_{1}: \text { Total number of taxa } \\
M_{2}: \text { Number of aquatic insect taxa } \\
M_{3}: \text { Number of Chironomidae taxa } \\
M_{4}: \text { Number of Ephemeroptera taxa } \\
M_{5}: \text { Number of Mollusca \& Crustacea taxa } \\
M_{6}: \text { Shannon-Wiener species diversity index } \\
M_{7}: \text { Simpson species diversity index } \\
M_{8}: \text { Margalef species richness diversity index } \\
M_{9}: \text { Pielou evenness index }\end{array}$ & $\begin{array}{l}\text { Decrease } \\
\text { Decrease } \\
\text { Increase } \\
\text { Decrease } \\
\text { Decrease } \\
\text { Decrease } \\
\text { Increase } \\
\text { Decrease } \\
\text { Decrease }\end{array}$ \\
\hline Taxonomic composition & $\begin{array}{l}M_{10}: \text { Goodnight-Whitley index } \\
M_{11}: \% \text { Chironomidae taxa } \\
M_{12}: \% \text { Chironomidae individuals } \\
M_{13}: \% \text { Crustacea taxa } \\
M_{14}: \% \text { Crustacea individuals } \\
M_{15}: \% \text { Mollusca \& Crustacea individuals } \\
M_{16}: \% \text { Gastropoda individuals } \\
M_{17}: \% \text { Pelecypoda individuals } \\
M_{18}: \% \text { Corbicula individuals } \\
M_{19}: \% \text { Diptera taxa } \\
M_{20}: \% \text { Diptera individuals } \\
M_{21}: \% \text { Ephemeroptera individuals } \\
M_{22}: \% \text { Oligochaeta individuals }\end{array}$ & $\begin{array}{l}\text { Increase } \\
\text { Increase } \\
\text { Increase } \\
\text { Increase } \\
\text { Increase } \\
\text { Decrease } \\
\text { Decrease } \\
\text { Decrease } \\
\text { Increase } \\
\text { Increase } \\
\text { Increase } \\
\text { Decrease } \\
\text { Increase }\end{array}$ \\
\hline $\begin{array}{l}\text { Equitability } \\
\text { Tolerance and intolerance index }\end{array}$ & $\begin{array}{l}\mathrm{M}_{23}: \text { Mollusca \& Diptera abundance } \\
\mathrm{M}_{24}: \text { Number of intolerant taxa }(\mathrm{PTV}<4) \\
\mathrm{M}_{25}: \% \text { intolerant taxa } \\
\mathrm{M}_{26}: \% \text { intolerant individuals } \\
\mathrm{M}_{27}: \text { number of tolerant taxa }(\mathrm{PTV}>6) \\
\mathrm{M}_{28}: \% \text { tolerant taxa } \\
\mathrm{M}_{29}: \% \text { tolerant individuals } \\
\mathrm{M}_{30}: \text { number of facultative taxa }(4 \leq \mathrm{PTV} \leq 6) \\
\mathrm{M}_{31}: \% \text { facultative taxa Increase } \\
\mathrm{M}_{32}: \% \text { facultative individuals } \\
\mathrm{M}_{33}: \text { Hilsenhoff biotic index }(\mathrm{HBI})\end{array}$ & $\begin{array}{l}\text { Increase } \\
\text { Decrease } \\
\text { Decrease } \\
\text { Decrease } \\
\text { Increase } \\
\text { Increase } \\
\text { Increase } \\
\text { Increase } \\
\text { Increase } \\
\text { Increase }\end{array}$ \\
\hline Functional feeding group index & $\begin{array}{l}\mathrm{M}_{34}: \% \text { Scrapers individuals Decrease } \\
\mathrm{M}_{35}: \% \text { Predators individuals } \\
\mathrm{M}_{36}: \% \text { Collector-gathers individuals } \\
\mathrm{M}_{37}: \% \text { Collector-filterers individuals } \\
\mathrm{M}_{38}: \% \text { Shredder individuals } \\
\mathrm{M}_{39}: \text { Scrapers/Collector individuals }\end{array}$ & $\begin{array}{l}\text { Increase } \\
\text { Decrease } \\
\text { Decrease } \\
\text { Decrease } \\
\text { Decrease }\end{array}$ \\
\hline
\end{tabular}

Mi: macroinvertebrate index. 
As in (1), $\sum_{1}$ and $\sum_{2}$ are the sum of scores of algae metric (P) $i$, and macroinvertebrate metrics (M) $j$, respectively, and the polluted degree was negative correlation with the LMII scores. As in (2), $p_{i=} C_{i} C_{0 i}$, where $C_{i}$ is the potential stressors concentration, $C_{0 i}$ is the third Chinese water quality standard value; $\omega_{i 1}=p_{i} / \sum_{1} p_{i}\left(p_{i}>1\right), \sum_{1}$ is the sum of $p_{i}\left(p_{i}>1\right), \omega_{i 2}=p_{i} / \sum_{2} p_{i}, \sum_{2}$ is the sum of $p_{i}$, and the polluted degree was positive correlation with the PI scores.

\section{RESULTS}

\section{Species composition of algae and macroinvertebrates}

A total of 83 species of algae were obtained through sampling from 10 sections in three regions of Dongting Lake: 34 species of Chlorophyta, 26 species of Bacillariophyta, 10 species of Cyanophyta, 5 species of Pyrrophyta, 4 species of Euglenophyta, 2 species of Cryptophyta, 1 species of Chrysophyta and 1 species of Xanthophyta, accounting for $40.96 \%, 31.32 \%, 12.05 \%, 6.02 \%, 4.82 \%$, $2.41 \%, 1.21 \%$ and $1.21 \%$ of the total number of collected species, respectively.

A total of 48 species of macroinvertebrate were obtained through sampling from 10 sections in three regions of Dongting Lake: 22 species of Mollusca, 16 species of Arthropoda and 10 species of Annelida, accounting for $45.83 \%, 33.33 \%$ and $20.83 \%$ of the total number of collected species, respectively.

\section{Evaluation of metrics}

Following the water quality criteria derived from Chinese surface water quality standard, three sections (S1, S3 and S4) were determined as reference sections, the remained 7 sections were impaired sections. The information of water quality measures and characterization was shown in Tab. 4.

\section{Discriminatory power}

On the basis of this classification, of 17 algae metrics and 39 macroinvertebrate metrics evaluated, 10 algae (Supplementary Fig. 1) and 16 macroinvertebrate (Supplementary Fig. 2) metrics scored a 2 or 3 in discriminatory power between reference and impaired sections. The 10 algae metrics were P1, P3, P5, P8, P10, P11, P14, P15, P16 and P17. The 16 macroinvertebrate metrics were M1, M2, M3, M5, M6, M7, M8, M11, M12, M27, M28, M29, M30, M31, M32 and M35.

\section{Redundancy}

Among the 10 algae metrics, several pairs or groups were highly correlated and considered redundant (Tab. 5), including P14 and P17 ( $\mathrm{r}=0.780, \mathrm{P}<0.01)$, as were $\mathrm{P} 3$ and

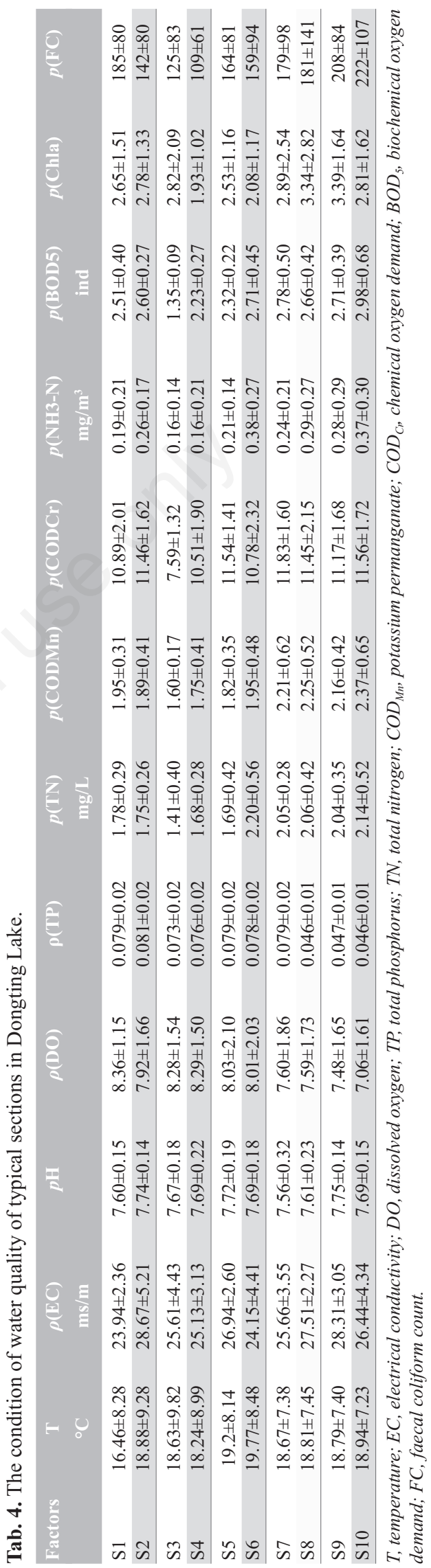


$\mathrm{P} 8(\mathrm{r}=0.892, \mathrm{P}<0.01)$. Finally we selected $\mathrm{P} 3$ and $\mathrm{P} 17$ from the two groups of redundant metrics. Six other metrics that were not redundant with any metrics were also candidates for final selection, leaving a total of eight algae metrics as candidates for the further screen.

Among the 16 macroinvertebrate metrics, several pairs or groups were highly correlated and considered redundant (Tab. 6), including M1, M2, M3, M5, M6, M7, M8, M27 and M30 (all $\mathrm{r}>0.75, \mathrm{P}<0.01$ ). M11, M12 and M28 were redundant $(\mathrm{r}>0.75, \mathrm{P}<0.01)$ as were $\mathrm{M} 29, \mathrm{M} 31$, and M32 $(\mathrm{r}=0.780, \mathrm{P}<0.01)$. Finally we selected M1, M12 and M32 from the three groups of redundant metrics. M35, which was not redundant with any metrics, was also a candidate for final selection, leaving a total of 4 macroinvertebrate metrics as candidates for the further screen.

\section{Relationship to stressors}

The results of principal component analysis showed that $\mathrm{DO}, \mathrm{COD}_{\mathrm{Mn}}, \mathrm{COD}_{\mathrm{Cr}}, \mathrm{BOD}_{5}, \mathrm{NH}_{3}-\mathrm{N}, \mathrm{TN}$ and TP were the main factors influencing the water quality of Dongting Lake (Supplementary Tab. 1).

P11, P16 and P17 were highly correlated with DO, $\mathrm{COD}_{\mathrm{Mn}}$ and $\mathrm{NH}_{3}-\mathrm{N}$, respectively, and $\mathrm{P} 11$ was also correlated with $\mathrm{DO}$ and $\mathrm{TN}$ as was $\mathrm{P} 16$ with $\mathrm{COD}_{\mathrm{Mn}}$ and $\mathrm{TN}$; P1, P3 and P9 were highly correlated with TP and were also correlated with $\mathrm{COD}_{\mathrm{Cr}}$ and $\mathrm{BOD}_{5} ; \mathrm{P} 5$ and $\mathrm{P} 10$ were correlated with TP, but little correlated with other factors (Fig. 2a). Finally we selected P1, P3, P9, P11, P16 and P17 as the algae component of LMII.

M32 was highly correlated with $\mathrm{NH}_{3}-\mathrm{N}$, while M12 was highly correlated with $\mathrm{COD}_{\mathrm{Mn}}$ and $\mathrm{TN}$, and M35 was highly correlated with $\mathrm{DO}, \mathrm{COD}_{\mathrm{Cr}}$ and $\mathrm{BOD}_{5}$ as was $\mathrm{M} 1$ with TP (Fig. 2b). Finally we selected M1, M12, M32, and M35 as the macroinvertebrate component of LMII.

\section{Scoring of metrics}

Frequency distribution statistics and scoring criteria of 10 finally selected metrics were list in Tab. 7. Based on the scoring of each metric, a multimetric on a scale ranging from 10 to 50 for bioassessment was developed
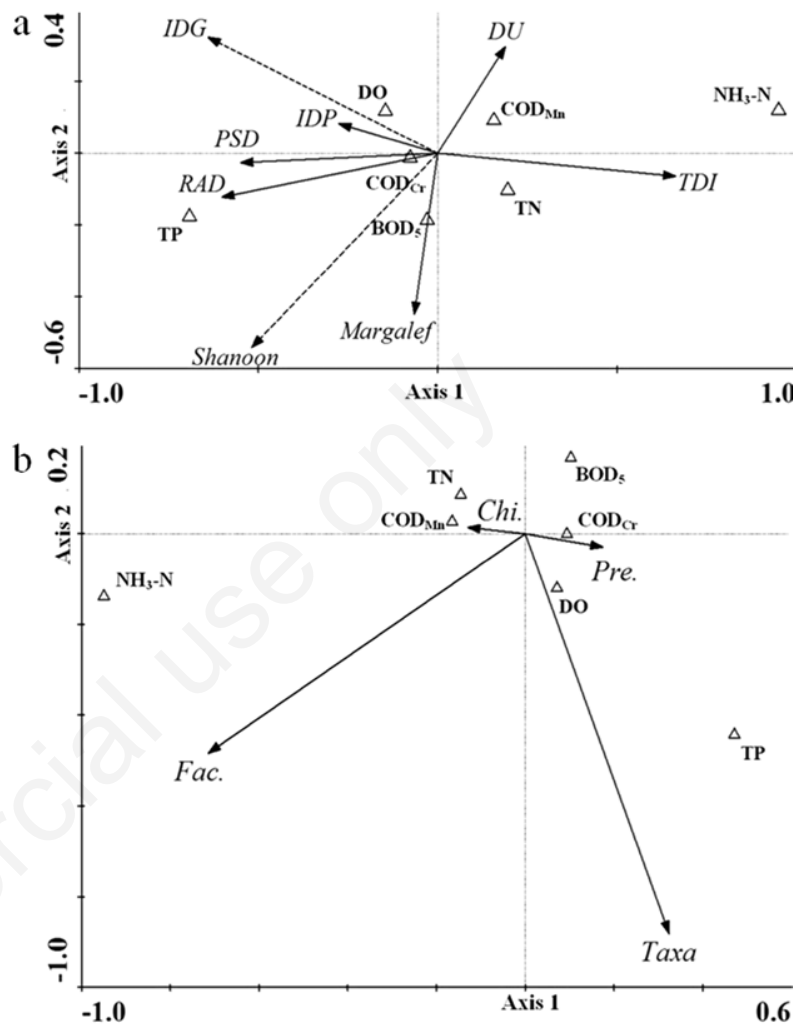

Fig. 2. CCA analysis between candidate metrics and majority environmental factors. a) Algae; IDG, Generic Diatom Index; IDP, Pampean Diatom Index, PSD, Percent Sensitive Diatoms; RAD, Relative Abundance Diatoms; Shanoon, Shannon-Wiener; Margalef, Margalef; DU,Diatom Quotient; TDI, Trophic Diatom Index. b) Macroinvertebrate; Fac., facultative individuals \%; Chi., Chironomidae individuals \%; Pre., predators individuals $\%$; Taxa, total taxa for benthos.

Tab. 5. Pearson correlation analysis of 10 algae candidate metrics.

\begin{tabular}{|c|c|c|c|c|c|c|c|c|c|c|}
\hline & $P_{1}$ & $\mathbf{P}_{3}$ & $P_{5}$ & $\mathbf{P}_{8}$ & $P_{10}$ & $P_{11}$ & $\mathbf{P}_{14}$ & $\mathbf{P}_{15}$ & $P_{16}$ & $\mathbf{P}_{17}$ \\
\hline $\mathrm{P}_{1}$ & 1.000 & & & & & & & & & \\
\hline $\mathrm{P}_{3}$ & 0.183 & 1.000 & & & & & & & & \\
\hline $\mathrm{P}_{5}$ & $0.680^{*}$ & $0.675^{*}$ & 1.000 & & & & & & & \\
\hline $\mathrm{P}_{8}$ & 0.108 & $0.892^{* *}$ & 0.561 & 1.000 & & & & & & \\
\hline $\mathrm{P}_{10}$ & 0.296 & -0.087 & -0.087 & $0.729^{*}$ & 1.000 & & & & & \\
\hline $\mathrm{P}_{11}$ & -0.068 & 0.036 & 0.079 & 0.158 & 0.380 & 1.000 & & & & \\
\hline $\mathrm{P}_{14}$ & -0.213 & -0.437 & -0.104 & -0.214 & 0.590 & 0.379 & 1.000 & & & \\
\hline $\mathrm{P}_{15}$ & -0.126 & -0.339 & -0.157 & -0.126 & 0.137 & -0.515 & 0.496 & 1.000 & & \\
\hline$P_{16}$ & -0.368 & 0.127 & -0.240 & 0.189 & -0.050 & 0.532 & 0.051 & -0.471 & 1.000 & \\
\hline $\mathrm{P}_{17}$ & 0.103 & -0.361 & 0.030 & -0.118 & $0.729^{*}$ & 0.217 & $0.780^{* *}$ & 0.388 & 0.164 & 1.000 \\
\hline
\end{tabular}

${ }^{*} P<0.05 ;{ }^{* *} P<0.01$. 
for each section by addition of the 10 metrics. Four levels of discriminatory biocriteria for water quality were eventually obtained by quartation: $10-20$, poor; $21-30$, fair; $31-$ 40 , good; 41-50, very good.

Re-scoring of the 10 sections was carried out based on the established water quality biocriteria, and the results showed that the water quality of western Dongting Lake was good, and southern Dongting Lake was relatively good, whereas that of eastern Dongting Lake was relatively poor (Fig. 3a), indicating that Dongting Lake was suffering from some pollution stress, especially in the eastern part of the lake.

\section{Power and accuracy analysis}

As the results shown that the LMII score was the same between Poutou (S1) and Hengling Lake (S5), but the polluted degree of S1 was higher than S5, so the similarity rate of the results was $80 \%$ between the scores of LMII
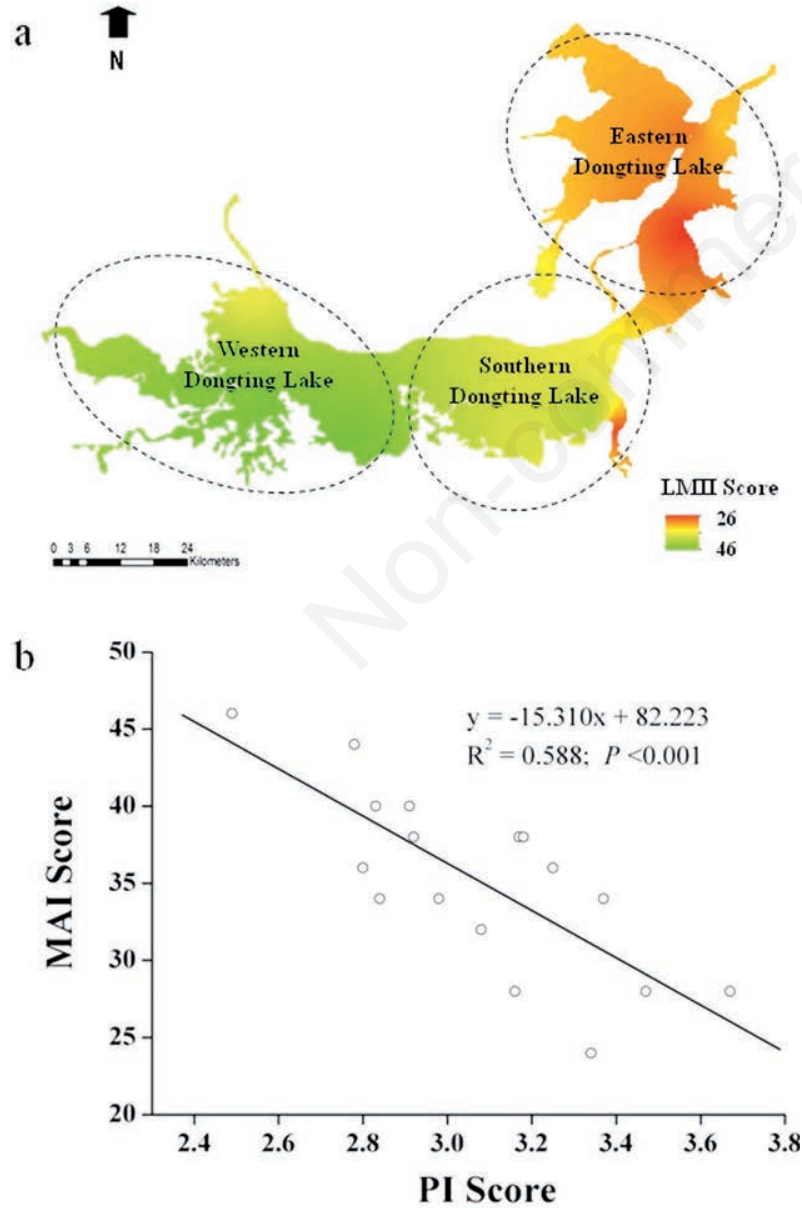

Fig. 3. Assessment of water quality using MAI and PI during 2012 in Dongting lake. a) Bioassessment of water quality using MAI. b) Relationship between MAI score and PI score.

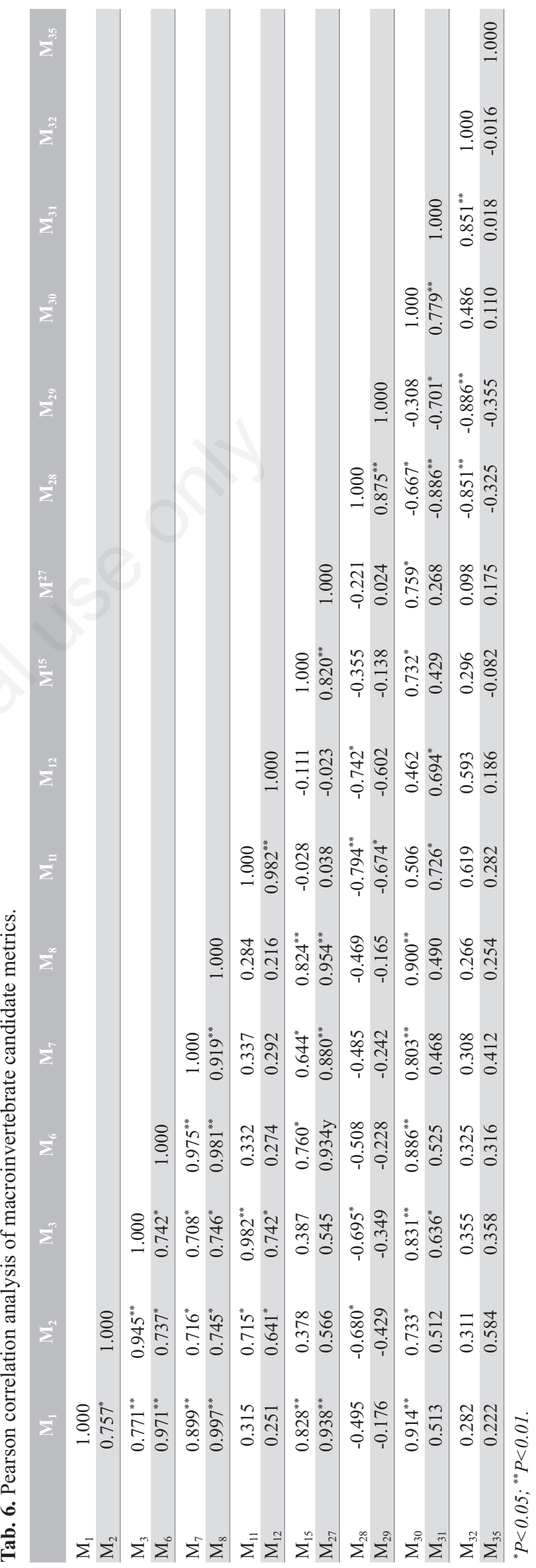


and PI in 2012 (Supplementary Tab. 2). Similarly, the LMII score of Yugongmiao (S6) was higher than Lujiao (S7), but the polluted degree of S6 was higher than S7, so the similarity rate of the results was $71.4 \%$ between the scores of LMII and PI in 2011 (Supplementary Tab. 3). Overall, the result of the Spearman rank showed high correlation $(\mathrm{r}=0.766, \mathrm{P}<0.001)$ between LMII Score and PI Score (Fig. 3b).

All of the power and accuracy analysis indicated that the LMII could reflect the water status of Dongting Lake and was suitable for bioassessment of Donting Lake.

\section{DISCUSSION}

\section{Selection of metrics}

When we choose biometrics to assess ecological (sub)regions, the obtained metrics could reflect the community structure and functional characteristics of algae or benthic macroinvertebrates more accurately based on reference sites, and the influences on accuracy of assessment results caused by sampling errors could be also decreased. Additionally, it should be necessary to prepare more candidate metrics, in order to screen a group of suitable metrics to carry out bioassessment of water quality (Resh et al., 1995). In this study, the selection of candidate metrics was mainly performed following the universality of a metric and species composition of algae and macroinvertebrates at sampling sections in order to avoid extensive calculation and statistic analysis.

\section{Discrimination of reference and impaired sections}

Studies had shown that the low sensitivity metrics can be cancelled by boxplot method based on the reference and impaired sites information of aquatic organisms, and a biological integrity index which reflects species composition and environmental stresses from different sides can be established via Spearman correlation analysis (Barbour et al., 1996). The reference condition approach
(RCA) has recently emerged as a broadly applicable protocol to monitor quality of streams, rivers, and lakes at regional level (Tall et al., 2008). Usually, it is difficult to define the actual reference site in a homogeneous ecological region owing to frequent occurrence of pollution in freshwater bodies of China. So in this study, the classification of reference and impaired sections was only a relative division. Generally, there are 2 methods including Shannon-Wiener species diversity index method (Huang et al., 1982; Wang and Yang, 2003), and physico-chemical index method (Stribling et al., 1998), through which the reference and impaired sites can be differentiated. Simple calculation is needed when Shannon-Wiener species diversity index method is employed; however, it has a low accuracy or some misjudgments because of limitation of sampling and tolerance values of different algae and macroinvertebrates. So we used the physicochemical index method because its undoubtedly more powerful than the first method, thus classification of reference and impaired sections could be carried out.

\section{Power and accuracy of the LMII}

When comparing the results of water quality assessment by using established biocriteria with that of water quality assessment by using main water quality parameters (Fig. 3b, Supplementary Tabs. 2 and 3), it was found that the 2 assessment results were completely consistent in most regions of Dongting Lake including western, southern and eastern coastal area, the similarity rate of the results of the two assessment methods were more than $60 \%$, and the result of the Spearman rank showed high correlation $(\mathrm{r}=0.766, \mathrm{P}<0.001)$ between LMII Score and PI Score (Fig. 3b), so the established algae and macroinvertebrate-based biocriteria are basically suitable for water quality assessment in different areas of Dongting Lake. In our study, the water quality status in the three regions of Dongting Lake was arranged based on the assessment results of biocriteria and water quality parameters,

Tab. 7. Frequency distribution statistics of the final metrics and its scoring criteria.

\begin{tabular}{|c|c|c|c|c|c|c|c|c|}
\hline \multirow[t]{2}{*}{ Metrics } & \multicolumn{5}{|c|}{ Frequency distribution } & \multicolumn{3}{|c|}{ Score } \\
\hline & Min & $5^{\text {th }}$ percentile & $50^{\text {th }}$ percentile & $95^{\text {th }}$ percentile & Max & 5 & 3 & 1 \\
\hline Relative abundance diatoms & 0.27 & 0.32 & 0.50 & 0.58 & 0.61 & $>0.50$ & $0.32 \sim 0.50$ & $<0.32$ \\
\hline Margalef for algae & 1.10 & 1.11 & 1.35 & 1.46 & 1.51 & $>1.35$ & $1.11 \sim 1.35$ & $<1.11$ \\
\hline Percent sensitive diatoms & 0.20 & 0.21 & 0.28 & 0.35 & 0.38 & $>0.28$ & $0.21 \sim 0.28$ & $<0.21$ \\
\hline Diatom quotient & 0.37 & 0.39 & 0.70 & 1.19 & 1.36 & $<0.70$ & $0.70 \sim 1.19$ & $>1.19$ \\
\hline Trophic diatom index & 45.61 & 48.12 & 59.15 & 66.84 & 67.22 & $<59.15$ & $59.15 \sim 66.84$ & $>66.84$ \\
\hline Pampean diatom index & 1.98 & 2.00 & 2.11 & 2.21 & 2.25 & $>2.11$ & $2.00 \sim 2.11$ & $<2.00$ \\
\hline Total taxa for benthos & 2.50 & 2.84 & 4.63 & 8.16 & 8.50 & $>4.63$ & $2.84 \sim 4.63$ & $<2.84$ \\
\hline Chironomidae individuals \% & 0 & 0.004 & 0.04 & 0.27 & 0.31 & $<0.04$ & $0.04 \sim 0.27$ & $>0.27$ \\
\hline Facultative individuals \% & 0 & 0.05 & 0.233 & 0.38 & 0.41 & $<0.23$ & $0.23 \sim 0.38$ & $>0.38$ \\
\hline Predators individuals \% & 0 & 0 & 0.07 & 0.23 & 0.30 & $<0.07$ & $0.07 \sim 0.23$ & $>0.23$ \\
\hline
\end{tabular}


as follows: western Dongting Lake > southern Dongting Lake > eastern Dongting Lake (Fig. 3a), which was completely consistent with previous researchs (Zhong and Chen, 2011; Zhou et al., 2011; Wang et al., 2013). However, obvious inconsistency between assessment results occurred in western and southern Dongting Lake (data not shown). For example, the section of Potou was assessed as an impaired section in the bioassessment of 2011 and 2012, which was contrary to the result of reference section based on the water quality parameters, the discrepancy between the two results may be caused by the high variability of macroinvertebrate and large amount of tolerant alien species in Potou sustained too much upland water. Alternatively, equivalence phenomena of the LMII score in several sections arisen in this study, the bioassessment of Potou and Hengling Lake had the same score in 2012, so it was difficult to compare the water quality status of the two sections in detail. Therefore, more available biometrics need to be screened and incorporated into the LMII, so as to compare the status of sections more exactly and further improve the results of water quality assessment by using established biocriteria.

Over all, the factors of habitat, hydrology, physics and chemistry, human activities, for example, flow velocity, climate, land use, man-made dams, cultivation, deforestation and so on, which can influence the power and accuracy of the assessment results were not yet considered into the LMII. So the LMII with comprehensive assessment system needs to be established, so as to improve the power and accuracy of the assessment index.

\section{CONCLUSIONS}

In our present study, we chose algae and macroinvertebrate metrics to establish the integrity index, so as to supply more different types for promoting the accuracy of assessment results and reduce the sampling errors on one kind of aquatic organism. However, the amount of algae candidate metrics and reference sections were relative less to carry out the bioassessment of water quality of Dongting Lake more accurately and sustainable. The appropriate location and number of sampling sites should be critical in obtaining true water quality of Dongting Lake when using the established biocriteria in our next work. Additionally, more metrics belonging to habitat, hydrology, physics and chemistry should also be considered into the LMII, so as to establish comprehensive assessment system which can reflect the community structure of aquatic organisms, physical and chemical characteristics of water environment, human activities, and so on.

\section{ACKNOWLEDGMENTS}

The study was financially supported by National Basic Research Program of China (2012CB417004), National
Science and Technology Pillar Program (2014BAC09B02) and Dongting Lake Key Station Ecological Monitoring Program of Rivers and Lakes (JJ2015-022). We thank Daizhong Huang, Qi Tian for their valuable sampling and experimental assistance.

\section{REFERENCES}

Angermeier PL, Smogor RA, Stauffer JR, 2000. Regional frameworks and candidate metrics for assessing biotic integrity in mid-Atlantic highland streams. T. Am. Fish. Soc. 129:962-981.

Barbour MT, Gerritsen J, Griffith GE, Frydenborg R, McCarron E, White JS, Bastian ML, 1996. A framework for biological criteria for Florida streams using benthic macroinvertebrates. J. N. Am. Benthol. Soc. 15:185-211.

Barbour MT, Gerritsen J, Snyder BD, Stribling JB, 1999. Rapid bioassessment protocols for use in streams and wadeable rivers. Washington DC, US EPA.

Bellinger BJ, Cocquyt C, O'Reilly CM, 2006. Benthic diatoms as indicators of eutrophication in tropical streams. Hydrobiologia 573:75-87.

Blocksom KA, Kuptenbach JP, Klemm DJ, Fulk FA, Cormier SM, 2002. Development and evaluation of the lake macroinvertebrate integrity index (LMII) for new Jersey lakes and reservoirs. Environ. Monit. Assess. 77:311-333.

Blocksom KA, Johnson BR, 2009. Development of a regional macroinvertebrate index for large river bioassessment. Ecol. Indic. 9:313-328.

Chessman BC, Williams SA, Besley C, 2007. Bioassessment of streams with macroinvertebrates: effect of sampled habitats and taxonomic resolution. J. N. Am. Benthol. Soc. 26:546-565.

China EPA, 2002. Methods for the monitoring and analysis of water and wastewater. 4. Chinese Environmental Science Press, Beijing.

Chon TS, Qu XD, Cho WS, Hwang HJ, Tang HQ, Liu YD, Choi JH, Jung M, Chung BS, Lee HY, 2013. Evaluation of stream ecosystem health and species association based on multitaxa (benthic macroinvertebrates, algae, and microorganisms) patterning with different levels of pollution. Ecol. Inform. 17:58-72.

Dai YZ, Tang SY, Zhang JB, 2000. [The distribution of zoobenthos species and bioassessment of water quality in Dongting Lake].[Article in Chinese]. Acta Ecol. Sin. 20:277-282.

Du Y, Cai S, Zhang XY, Zhao Y, 2001. Interpretation of the environmental change of Dongting Lake, middle reach of Yangtze River, China, by $210 \mathrm{~Pb}$ measurement and satellite image analysis. Geomorphol. 41:171-181.

EPA, 1998. Lake and reservoir bioassessment and biocriteria: technical guidance document, EPA 841-B-98-007. U.S. EPA, Washington: $257 \mathrm{pp}$.

EPA, 1999. Rapid bioassessment protocols for use in wadeable streams and rivers. EPA 841B-99-002. U.S. EPA, Washington: 339 pp.

Griffith MB, Hill BH, McCormick FH, Kaufmann PR, Herlihy AT, Selle AR, 2005. Comparative application of indices of biotic integrity based on periphyton, macroinvertebrates, and fish to southern Rocky Mountain streams. Ecol. Indic. 5:117-136.

Gomez N, Licuris M, 2001. The Pampean Diatom Index (IDP) 
for assessment of rivers and streams in Argentina. Aquat. Ecol. 35:173-181.

Hill BH, Herlihy AT, Kaufmann PR, DeCelles SJ, Vander Borgh MA, 2003. Assessment of streams of the eastern United States using a periphyton index of biotic integrity. Ecol. Indic. 2:325-338.

Huang YY, Teng DX, Zhao ZX, 1982. [Monitoring Jiyunhe estuary pollution by use of macroinvertebrate community and diversity index].[Article in Chinese]. Sinozool. 2:133-146.

Kane DD, Gordon SI, Munawar M, Charlton MN, Culver DA, 2009. The Planktonic Index of Biotic Integrity (P-IBI): an approach for assessing lake ecosystem health. Ecol. Indic. 9:1234-1247.

Kelly MG, Whitton BA, 1995. The Trophic Diatom Index: a new index for monitoring eutrophication in rivers. J. Appl. Phycol. 7:433-444.

Kerans BL. Karr JR, 1994. A benthic index of biotic integrity (BIBI) for rivers of the Tennessee Valley. Ecol. Appl. 4:768-785.

Klemm DJ, Blocksom KA, Fulk FA, Herlihy AT, Hughes RM, Kaufmann PR, Peck DV, Stoddard JL, Thoeny WT, Griffith MB, Davis WS, 2003. Development and evaluation of a macroinvertebrate biotic integrity index (MBII) for regionally assessing mid-Atlantic highlands streams. Environ. Manage. 31:656-669.

Lane CR, Brown MT, 2007. Diatoms as indicators of isolated herbaceous wetland condition in Florida, USA. Ecol. Indic. 7:521-540.

Li Q, 2005. [Hygrophilous ecological environment succession and countermeasure of the Dongting Lake].[Article in Chinese]. Res. Soil Water Conserv. 12:98-100.

Li YS, Raso G, Zhao ZY, He YK, Ellis MK, McManus DP, 2007. Large water management projects and schistosomiasis control, Dongting Lake Region, China. Emerg. Infec. Dis. 13:973-979.

Lin ZZ, 1985. [Calculate the mixed weighted model of environmental quality comprehensive index].[Article in Chinese]. Environ. Sci. 6:67-69.

Ma TW, Huang QH, Wang H, Wang ZJ, Wang CX, Huang SB, 2008. [Selection of benthic macroinvertebrate-based multimetrics and preliminary establishment of biocriteria for the bioassessment of the water quality of Taihu Lake, China].[Article in Chinese]. Acta Ecol. Sin. 28:1192-1200.

Maxted JR, Barbour MT, Gerritsen J, Poretti V, Primrose N, Silvia A, Penrose D, Renfrow R, 2000. Assessment framework for mid-Atlantic coastal plain streams using benthic macroinvertebrates. J. N. Am. Benthol. Soc. 19:128-144.

McCormick FH, Hughes RM, Kaufmann PR, Peck DV, Stoddard JL, Herlihy AT, 2001. Development of an index of biotic integrity for the mid-Atlantic highlands streams. T. Am. Fish. Soc. 130:857-877.

Menetrey N, Oertli B, Lachavanne JB, 2011. The CIEPT: a macroinvertebrate-based multimetric index for assessing the ecological quality of Swiss lowland ponds. Ecol. Indic. 11:590-600.

Miller SJ, Wardrop DH, Mahaney WM, Brooks RP, 2006. A plant-based index of biological integrity (IBI) for headwater wetlands in central Pennsylvania. Ecol. Indic. 6:290-312.

Muscio C, 2002. The diatom pollution tolerance index: assigning tolerance values. City of Austin Watershed Protection \& Development Review Department.

O'Connor RJ, Walls TE, Hughes RM, 2000. Using multiple tax- onomic groups to index the ecological condition of lakes. Environ. Monit. Assess. 61:207-228.

Ogren SA, Huckins C, 2014. Evaluation of suitability and comparability of stream assessmentindices using macroinvertebrate data sets from the Northern Lakes and Forests Ecoregion. Ecol. Indic. 40:117-126.

Plafkin JL, Barbour MT, Porter KD, Gross SK, Hughes RM, 1989. Rapid bioassessment protocols for use in streams and rivers: benthic macroinvertebrates and Fish. EPA 440/489/001. U.S. Environmental Protection Agency.

Resh VH, Norris RH, Barbour MT, 1995. Design and implementation of rapid assessment approaches for water resource monitoring using benthic macroinvertebrates. Aust. J Ecol. 20:108-121.

Shen YF, Zhang ZS, Gong XJ, 1990. [New technology of micro biological monitoring].[Book in Chinese]. China Building Industry Press, Beijing: 133 pp.

Stribling JB, Jessup BK, White JS, 1998. Chesapeake Bay and watershed programs (monitoring and non-tidal assessment): development of a benthic index of biotic integrity for Maryland streams. Report No. CBWP-MANTA-EA-98-3. Department of Natural Resources, Annapolis.

Tall L, Methot G, Armellin A, Pinel-Alloul B, 2008. Bioassessment of benthic macroinvertebrates in wetland habitats of Lake Saint-Pierre (St. Lawrence River). J. Great Lakes Res. 34:599-614.

Wang BX, Yang LF, 2003. [Bioassessment of Qinhuai River using a river biological index].[Article in Chinese]. Acta Ecol. Sin. 23: 2082-2091.

Wang LJ, Wang X, Liu LS, Zheng BH, Li LQ, Huang DZ, Tian Q, 2013. Multivariate analysis of water factors in Dongting Lake. Res. Environ. Sci. 26:1-7.

Wang X, Zheng BH, Liu LS, Wang LJ, Li LQ, Huang DZ, 2012. [Correlation analysis of macroinvertebrate composition and environmental factors of typical sections in Dongting Lake].[Article in Chinese]. China Environ. Sci. 32: 2237-2244.

Weigel BM, Henne LJ, Martinez-Rivera LM, 2002. Macroinvertebrate-based index of biotic integrity for protection of streams in west-central Mexico. J. N. Am. Benthol. Soc. 21:686-700.

Whittier TR, Hughes RM, Stoddard JL, Lomnicky GA, Peck DV, Herlihy AT, 2007. A structured approach for developing indices of biotic integrity: three examples from streams and rivers in the western USA. T. Am. Fish. Soc. 136:718-735.

Wilcox DA, Meeker JE, Hudson PL, Armitage BJ, Black MG, Uzarski DG, 2002. Hydrologic variability and the application of index of biotic integrity metrics to wetlands: a great lakes evaluation. Wetlands 22:588-615.

Wu NC, Cai QH, Fohrer N, 2012. Development and evaluation of a diatom-based index of biotic integrity (D-IBI) for rivers impacted by run-of-river dams. Ecol. Indic. 18:108-117.

Wu JT, Kow LT, 2002. Applicability of ageneric index for diatom assemblages to monitor pollution in the tropical River Tsanwun, Taiwan. J. Appl. Phycol. 14:63-69.

Xie ZC, Zhang JQ, Chen J, Ma K, Liu RQ, Wang YP, Cai QH, 2007. [Spatial distributional pattern of macrozoobenthos and pollution evaluation in East Lake Dongting Reserve].[Article in Chinese]. J. Lake Sci. 19:289-298.

Yin XW, Qu XD, Li QN, Liu Y, Zhang Y, Meng W, 2012. [Using periphyton assemblages to assess stream conditions of Taizi 
River Basin, China].[Article in Chinese]. Acta Ecol. Sin. 32:1677-1691.

Yoder CO, Rankin ET, 1995. Biological criteria program development and implementation in Ohio, p. 109-144. In: W.S. Davis and T.P. Simon (eds.), Biological assessment and criteria. Lewis Publ., Boca Raton.

Zalack JT, Smucker NJ, Vis ML, 2010. Development of a diatom index of biotic integrity for acid mine drainage impacted streams. Ecol. Indic. 10:287-295.

Zhang T, Li DL, Xu BH, Chen KJ, Xiao TY, Yang CZ, Liu YC,
2009. [Investigation on phytoplankton and water quality assessment of aquacultural waterbodies in west Dongting Lake area].[Article in Chinese]. J. Hydroecol. 2:12-18.

Zhong ZY, Chen C, 2011. [Water quality and eutrophication analysis in Lake Dongting].[Article in Chinese]. Environ. Sci. Manage. 36:169-173.

Zhou H, Ou FP, Liu Y, 2011. [The analysis of the water quality and its change trend of Dongting Lake during the period of "Eleventh Five-Year"].[Article in Chinese]. J. Hunan Inst. Sci. Technol. 24: 88-90. 